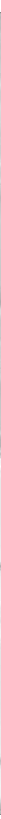

Bakgrunn: Utskriving fra sykehus til kommunal hjemmetjeneste er en sårbar situasjon for pasienter. Bruk av PLO-meldinger skal sikre at tilstrekkelig og relevant informasjon overføres ved pasientoverganger mellom sykehus og hjemmetjeneste. Sykepleiernes erfaringer med PLO-meldinger i utskrivningsprosessen er per i dag et lite utforsket område.

Hensikt: $\AA$ utforske sykepleiernes erfaringer med bruk av PLO-meldinger ved utskrivning av pasienter fra sykehus til kommunal hjemmetjeneste.
Metode: Kvalitativ studie med intervjuer av 41 helsearbeidere ved ett universitetssykehus og i tre kommuner.

Resultat: Bruk av PLO-meldinger bidro til raskere avklaring og tilgang til informasjon ved utskrivningsplanlegging og selve utskrivelsen av pasienter. Sykepleierne benyttet likevel supplerende informasjonskilder for å sikre overføring av tilstrekkelig informasjon mellom sykehus og hjemmetjeneste. Årsaken til dette var uforutsigbarhet knyttet til pasientens utreisedato, inkonsistens mellom pasientens legemiddelliste i kommuner og i sykehus, manglende informasjon i meldinger og forskjeller i faglig tilnærming mellom nivåene.

Konklusjon: PLO-meldinger er et nyttig kommunikasjonsverktøy. Det må likevel kompletteres med muntlig kommunikasjon og møter for å ivareta informasjonskontinuitet ved utskrivningsplanlegging og utskrivning av pasienter fra sykehus til hjemmetjeneste. Videre tiltak bør rettes mot hvordan informasjonsinnholdet i meldingenes fritekstfelter bør fremstå.
Electronic message exchange for patients discharged from hospital

Background: Discharge from hospital to community care services represents a particularly vulnerable situation for patients. Electronic messaging, with the use of «PLO»messages, has been introduced to ensure effective and safe information exchange in patient transitions between hospitals and community care services. As of today, little is known about the nurses' experiences with the use of «PLO»-messages during discharge.

Objective: To explore nurses' experiences with «PLO»-messages that support patient transitions from hospital to community care services.

Material and methods: A qualitative study with semi-structured interviews with 41 employees at a university hospital and three community care services.

Results: «PLO»-messages facilitated easy access to shared information during discharge planning as well as in the actual patient discharge. However, the use of supplementary communication channels was necessary to ensure informational continuity. The major reasons were unpre- dictable discharge dates, inconsistency in respective medication lists in community care service and hospital, lacking content in the messages' free text fields and cultural differences in nursing practice.

Conclusion: Whereas «PLO»messages serve as a beneficial communication tool, they have to be supplemented with oral communication and meetings to ensure informational continuity in the discharge planning and discharge. Further efforts should be directed towards improving the content of the free text fields of the messages. 


\section{Elektronisk meldingsutveksling ved utskrivning av pasienter fra sykehus til kommune}

Forfattere: Berit J. Brattheim, Ragnhild Hellesø og Line Melby

\section{NøKKELORD}

- Samhandling

- Eldreomsorg

- Kommunehelsetjeneste

- Spesialisthelsetjeneste

\section{INTRODUKSJON}

Samhandlingsreformen slår fast at kommunikasjon mellom helsepersonell fortrinnsvis skal være elektronisk (1). Målet er at alle sykehus og kommuner skal ha tatt i bruk elektronisk meldingsutveksling innen utgangen av 2015 (2). Hovedhensikten er at elektronisk kommunikasjon skal bidra til en mer effektiv og sikker samhandling om pasienter som forflyttes mellom sykehus og kommune (1).

Samhandlingsutfordringer i kontaktflaten mellom sykehus og kommune er godt dokumentert. Pasienter som skrives ut fra sykehus til kommunal helse- og omsorgstjeneste representerer en spesiell sårbar situasjon $(1,3)$ : De blir liggende på sykehus og vente på kommunale omsorgstilbud (4), det er ufullstendig eller uklart innhold i informasjonen som utveksles (5-7), og informasjonsflyten er mangelfull og preges av ineffektive kommunikasjonslinjer (8-10).
Organisatoriske faktorer som dårlig planlegging av pasientoverføring og liten kjennskap til pasientens tilstand skaper også utfordringer i kommunikasjonen mellom sykehus og kommune (11). Det samme gjelder kulturelle faktorer som ulik faglig tilnærming og forståelse av pasientens behov hos sykepleierne ved henholdsvis sykehus og kommune $(12,13)$. Videre viser både nasjonal og internasjonal litteratur at det ligger et potensial i det å kunne bruke informasjon- og kommunikasjonsteknologi (IKT) til å utveksle samhandlingsinformasjon (14-17).

Mangler i informasjonsutveksling og kommunikasjon mellom sykehus og kommune er alvorlig da dette kan føre til at pasientene ikke får den behandling og pleie de har behov for (18-20). For å sikre at tilstrekkelig og relevant informasjon overføres ved pasientoverganger mellom sykehus og kommune, er pleie- og omsorgsmeldinger (PLO-meldinger) innført som redskap for å bedre denne samhandlingen. PLO-meldinger omfatter et sett av flere standardiserte meldingstyper som understøtter fasene innleggelse, utredning/behandling og utskrivning ved et sykehus- opphold. I tillegg finnes det dialogmeldinger for mer løpende, interaktiv samhandling (se tabell 1) (21, 22). Per 1. januar 2015 hadde 99 prosent av alle kommuner (422/428) tatt i bruk PLO-meldinger i samhandling med sykehus. Dette er en sterk $ø$ kning fra fire kommuner i mai 2012 (23).

Det er begrenset med dokumentasjon av effekter av ulike samhandlingstiltak generelt (24), og for erfaringer med elektronisk meldingsutveksling mellom sykehus og kommunal helse- og omsorgstjeneste spesielt. Tilbakemeldinger fra bruk av elektronisk meldingsutveksling fra andre områder i helsesektoren rapporterer om gevinster som økt tilgjengelighet

\section{Hva tilfører artikkelen?}

Studiens overordnete funn viser at informantene var fornøyde med å kommunisere ved hjelp av PLOmeldinger.

\section{Mer om forfatterne:}

Berit J. Brattheim, førsteamanuensis, fakultet for helse-og sosialvitenskap, NTNU. Ragnhild Helles $\varnothing$, professor, Universitetet i Oslo, Avd for sykepleievitenskap. Line Melby, seniorforsker, Sintef. Kontaktperson: Berit.Brattheima hist.no. 
til nødvendig helseinformasjon, samt bedre kvalitet på informasjon som utveksles $(23,25,26)$. Alt i alt er det få studier som har sett direkte på hvordan samspillet mellom sykepleiere ved bruk av PLO-meldinger fungerer ved utskrivelse av pasienter fra sykehus til kommune.

Hensikten med denne studien er å utforske sykepleiernes erfaringer med bruk av PLOmeldinger ved utskrivning av pasienter fra sykehus til kommunal hjemmetjeneste. Studien tar utgangspunkt i begrepet informasjonskontinuitet slik det defineres av Haggerty et al. og Reid et al. (27,28): Her knyttes informasjonskontinuitet til overføring av «relevant og tilstrekkelig informasjon» mellom helsearbeidere i en kjede. Det vil si personlig informasjon om pasienten, helsetilstand og tidligere behandling, slik at videre tjenester kan gis i samsvar med pasientens behov for hjelp til rett tid.

\section{MATERIALE OG METODE}

$\mathrm{Vi}$ benyttet et eksplorerende, kvalitativt design med semistrukturerte individuelle intervjuer og gruppeintervjuer (8/14). Studien ble utført ved et universitetssykehus og i den kommunale hjemmetjenesten i tre kommuner i sykehusets opptaksområde. Strategisk utvalg ble benyttet for inklusjon av sykehus og en kommune, da disse var av de første som tok i bruk elektronisk meldingsutveksling. De to andre kommunene ble tilfeldig utvalgt.

Intervjuene ble gjennomført i perioden februar-november, 2014 og omfattet 41 ansatte. De fleste hadde vært ansatt ved nåværende enhet siden før samhandlingsreformen trådte i kraft i 2012. For å utvide vår forståelse for kompleksiteten i samhandlingskjeden, inkluderte

Tabell 1: PLO-meldingsportefølje i utskrivningsprosessen (basert på (38 og 40))

Sykehuset benytter følgende PLO-meldinger:

Helseopplysning ved søknad («Tidlig melding»):

Sendes innen 24 timer etter innleggelse. Den skal også sendes hvis pasienten vil ha behov for nye eller endrede tjenester fra kommunen. Meldingstypen skal inneholde beskrivelse av pasientens status, antatt forløp, forventet utreisedato og kontaktopplysninger. Den kan inneholde foreløpige medisinske opplysninger, for eksempel diagnose og kliniske funn, kritisk informasjon for eksempel allergier, opplysninger om pasientens egensøknad, foreløpige sykepleiefaglige opplysninger, for eksempel pleieplan og tiltak.

\section{Helseopplysninger-oppdatering}

Utskrivningsklar pasient:

Skal sendes når dette er avklart. Kommunen skal gi tilbakemelding på mottak av utskrivningsklar pasient.

\section{Avmelding om utskrivningsklar pasient:}

Sendes dersom pasienten likevel ikke er utskrivningsklar

\section{Melding om utskrevet pasient:}

Sendes med en gang pasienten er utskrevet

\section{Sykepleierapport:}

Tilsvarer dokumentet sykepleiesammenfatning. Skal sendes til kommunen ved utskrivelse.

\section{Dialogmeldinger:}

Benyttes ved mer løpende, interaktiv kommunikasjon som forespørsel og svar på forespørsel. vi helsepersonell i ulike roller. Ved sykehuset utgjorde dette 15 sykepleiere og to sosionomer ved ulike sengeposter fordelt på tre divisjoner. I kommunene intervjuet vi 24 ansatte: Tolv var utøvende sykepleiere i hjemmetjenesten, ti var sykepleiere $i$ henholdsvis koordinator-bestiller- eller virksomhetslederrollen, mens to var IT-ansvarlige. Hvert intervju varte i 40-50 minutter, ble tatt opp på bånd og transkribert. Intervjuguiden var utformet for å få frem helsepersonells synspunkter, vurderinger og erfaringer med bruk av PLO-meldinger, herunder type, hyppighet, deling av informasjon, om de fikk nok informasjon til å gi forsvarlig helsehjelp samt hvilke andre kommunikasjonsformer de benyttet. Alle forfatterne deltok i datainnsamlingen for å sikre nøyaktighet og konsistens i gjennomføringen.

I analysen benyttet vi en induktiv tilnærming (29). Alle tre forfatterne gikk først igjennom materialet og identifiserte overordnete temaer. Her fant vi at kommunikasjon og samarbeid i utskrivningsprosessen var et sentralt tema for informanter både i sykehus og i hjemmetjeneste, og vi besluttet å forfølge dette videre. $\mathrm{Vi}$ arbeidet med meningsfortetting og koding (30) for så å kategorisere materialet ut fra tre faser i et sykehusopphold: Innleggelse, utredning/behandling og selve utskrivelsen. Disse fasene representerte ulike kommunikasjons- og samarbeidsutfordringer. Til slutt gjennomgikk vi kategoriene i hver av de tre fasene og samlet dem under tre analytiske temaer. Disse danner strukturen i resultatkapitlet.

Prosjektet ble meldt til NSD og til helseforetakets personvernombud. Informantene ble rekruttert via sine ledere med skriftlig informasjon om prosjektet. Vi 
innhentet skriftlig samtykke fra alle deltakerne i studien.

\section{HOVEDFUNN}

Overordnete funn viser at informantene var fornøyde med å kommunisere ved hjelp av PLOmeldinger, både generelt og spesielt i tilknytning til planlegging av utskrivningsprosessen. Bruken av PLO-meldinger var godt innarbeidet i sykepleiernes arbeidshverdag og bidro til tettere samhandling på tvers av sykehus og kommuner. "Tidsbesparelse» var et begrep som gikk igjen i intervjuene.

Analysen viste at hver fase i et sykehusopphold innebærer ulike utfordringer for sykepleiere når de skal kommunisere og samarbeide om planlegging og gjennomføring av utskrivelsen. Allerede ved innleggelse skal helsepersonell anslå utskrivelsesdato, dette har vi kalt «å varsle det uforutsigbare». Under fasen utredning og behandling må sykepleierne i sykehus, og særlig i kommunen, holde seg oppdatert om pasientens progresjon. Samtidig må de starte planleggingen av hjelpetilbud til pasienten etter utskrivelse. Dette tar vi for oss i avsnittet «å holde i tråden». På utskrivningsdagen skal mye informasjon kommuniseres fra sykehus til kommune, og kommunen skal ha et egnet tilbud klart til pasienten. Vi kan betrakte det som «å samle trådene» som tas opp sist i resultatkapitlet.

\section{Å varsle det uforutsigbare}

Informasjon fra sykehus til kommunen om pasientens helsetilstand, hjelpebehov og forventet utreisetidspunkt skal skje innen 24 timer etter innleggelse. Her benyttet sykepleierne meldingstypen «Helseopplysninger ved søknad» («Tidligmelding»)

til kommunen. Det å angi forventet utreisedato var en utfordring for sykepleierne. Flere fortalte at det var sykepleierne selv, og ikke legen, som fastsatte datoen. Som oftest var dette basert på erfaring med hvor lang behandlingstid en spesifikk sykdomstilstand hadde. Det hendte også at pasientens tilstand var så dårlig at det var umulig å angi utreisedato. Sykepleierne informerte da kommunen om at estimert

trakk frem eksempler på at det å sende oppdaterte helseopplysningsskjemaer underveis $\mathrm{i}$ sykehusoppholdet, var godt innarbeidet i deres arbeidspraksis. Vi fant imidlertid at disse endringene og oppdateringene ikke alltid var tilstrekkelige for kommunen til å treffe beslutninger. For å innhente opplysninger de savnet, eller som måtte avklares nærmere med hensyn til pasientens helsetilstand og funksjonsnivå, kontaktet kommunen

\section{Bruken av PLO-meldinger var godt innar- beidet i sykepleiernes arbeidshverdag.}

utreisetidspunkt ville bli kommunisert underveis i pasientens sykehusopphold.

Det varierte hvordan kommunene forholdt seg til «Tidligmeldingen»; alt fra at ingen tiltak ble iverksatt til det å benytte meldingen som grunnlag for vedtaksbeslutninger. Det er uklart hva variasjonen skyldtes. En mulig forklaring kan være at det var tydelige individuelle forskjeller i hvordan sykepleierne fylte ut helseopplysningsskjemaet. Et par av sykehusets sykepleiere beskrev det slik: «Det er vel individuelt ... jeg ble opplært til at man bruker (pasientens) behandlingsplan. Her står det om (pasientens) kommunikasjonssans, aktivitetsnivå og så videre, og så fyller du ut hva som er aktuelt». Og: «Men jeg ser at det er mange hos oss som sender av gårde bare en linje, for eksempel at pasienten er innlagt for intravenøs antibiotikabehandling». Altså varierte både innhold og detaljeringsgrad i meldingene som ble oversendt til kommunen.

\section{Å holde tråden}

Sykepleierne på begge nivåer sykehuset via dialogmeldinger. Noen ganger hadde kommunen telefonsamtaler med sykehuset i tillegg. Som en informant uttrykte det: «Det er jo noen opplysninger som mangler - det er jo derfor vi ringer. $\mathrm{Og}-\mathrm{det}$ er noe med hva tenker man videre (for denne pasienten)?? Og med å komme litt under huden når det bare er noen få ord som er skrevet ned (i Helseopplysningsskjemaet)». Andre ganger benyttet kommunen vurderingsbesøk på sykehuset, men her varierte praksisen mellom kommunene. Informantene fremhevet at et vurderingsbesøk kunne avdekke uoverensstemmelser mellom sykehusets og kommunens beskrivelse av pasientens hjelpebehov. Dette hadde konsekvenser for hvilke omsorgstilbud pasienten skulle få etter utskriving: «Da har vi dem (pasientene) som vi er usikre på, eller dem som er nye for oss, eller dem som de beskriver at har et stort pleieog omsorgsbehov: Det er ikke alltid at det er det (riktige hjelpebehovet) som meldes. Så når vi er $\mathrm{i}$ beit og ingen har sett denne personen før, da reiser 
vi (på vurderingsbesøk) ... For det første, så blir hele saksbehandlingsbiten enklere for vår del ... og en annen ting er at vi har jo flere ganger endt opp med et helt annet tilbud (til pasienten) enn hva sykehuset melder» (Kommunen).

Vi fant at sykepleiere i både sykehus og kommune hadde behov for å vite at meldinger var mottatt av samhandlende helsepersonell. Imidlertid

systemet: "Men da er egentlig den lista veldig fin. For da har du hele tiden i minne hvem du egentlig skal etterlyse, eller lese om pasienten har kommet hjem (...) Ja - det er sånt skyggeregnskap». Tilsvarende fant vi eksempel på at sykehuset benyttet denne typen lister til å holde oversikter over pasienter inn og ut av en sengepost, eller for å identifisere behov for sykepleiefaglig støtte fra sykehuset for pasienter som

\section{Det å angi forventet utreisedato var en utfordring for sykepleierne.}

antydet sykehusets sykepleiere at det var ulike oppfatninger om i hvilken grad sykepleierne var forpliktet til å bekrefte mottak av PLO-meldinger: «Vi tenkte at det kanskje er et krav at kommunen må svare at PLO-meldingen er mottatt. Men noen kommuner sier: «nei, vi har ikke fått beskjed om at det er et krav'. Vi kan se at meldingen har gått, men vi kan ikke se de (kommunen) har lest den» (Sykehuset). For sykehuset var tilbakemeldinger en forutsetning for god planlegging av pasientens utreise. Det var viktig for å kunne orientere pasienten om hvilket tjenestetilbud vedkommende skulle skrives ut til, og for bestilling av ambulanse for transport av pasienten.

Både sykehus og kommuner benyttet PLO-meldingene til å holde oversikt over pasientstrømmer. Mer spesifikt, sykepleierne brukte innholdet i meldingene som grunnlag for å utarbeide egne manuelle lister, enten i papir eller elektronisk. Kommunen benyttet disse listene til å holde tråden i utskrivningsklare pasienter over tid. På den måten sikret de at ingen pasienter falt ut av ble skrevet ut til hjemmetjenesten: «Hvis pasienten skal hjem med CVK (sentralt venekateter), så trenger kommunen opplæring. Da må vi engasjere ambulerende team».

\section{Å samle trådene}

Selve utskrivningssituasjonen startet med at sykehusets sykepleiere sendte "Melding om utskrivningsklar pasient» til kommunen. I tillegg fylte sykepleierne ut og oversendte meldingstypen «Utskrivningsrapport». Enkelte sykepleiere fortalte at de også sendte med pasienten en papirutskrift av utskrivningsrapporten. En typisk situasjon var når pasienten ble skrevet ut på fredags ettermiddag: "Det er ikke alltid at pasienten kommer hjem i kontortiden slik at de (kommunen) som skal ta imot pasienten har tilgjengelig informasjon» (Sykehuset). I tillegg fikk pasienten med seg legemiddelliste og epikrisen, hvis denne var ferdigstilt, i papirformat.

Sykepleierne på sykehuset rapporterte at det kunne være vanskelig å fylle ut Utskrivningsrapporten. Dette skyldtes selve utformingen av meldingen. Den er «litt krøkkete», som en sykepleier uttrykte. Sykepleierne hadde en mal å gå etter, men de syntes at punktene i malen var overlappende. Noen opplevde det også som dobbeltarbeid siden utskrivningsrapporten var tilnærmet identisk med Helseopplysningsskjemaet, selv om de kunne gjenbruke tekst med klipp-og-lim-metoden.

Utøvende sykepleiere i kommunens hjemmetjeneste ble gjerne først involvert på selve utskrivningsdagen, ved mottak av meldingen Utskrivningsklar pasient. De fortalte at de innimellom opplevde at for kjente brukere kom meldingen med Utskrivningsrapporten fra sykehuset først et par dager etter brukerens hjemkomst. Dette var en utfordring de løste ved å ta kopi av papirversjonen brukeren hadde fått med seg fra sykehuset. For kommuner som ikke fikk overført pasientens legemiddelliste elektronisk, representerte papirversjonen som fulgte pasienten en ekstra utfordring. For eksempel opplevde sykepleierne ofte uoverensstemmelse mellom medbrakt legemiddelliste og de legemidlene pasienten sto på før innleggelse. Dette krevde ekstra arbeidsinnsats; fastlegen måtte kontaktes enten via elektroniske meldinger eller per telefon for å få bekreftet medisinendringer. Likeså måtte de bruke tid på å legge inn medisinendringene manuelt $\mathrm{i}$ journalen: "Så hender det jo at den listen (legemiddellista) ikke stemmer helt overens (med legemiddelliste før innleggelse), eller at det er piller som var på den gamle som vi tror han (pasienten) skal fortsette med. Så da må vi, når det blir hverdag, konferere med fastlegen om den [medisinen] virkelig skal seponeres eller...» (Kommunen). Det var ikke tilsva- 
rende utsagn der elektronisk legemiddelliste var tatt i bruk.

\section{DISKUSJON}

Hensikten med denne studien var å utforske sykepleiernes erfaringer med bruk av PLOmeldinger ved utskrivning av pasienter fra sykehus til kommune. Et hovedfunn var at sykepleierne var fornøyd med å kunne kommunisere og utveksle informasjon elektronisk. Bruken av PLO-meldinger var godt integrert i arbeidshverdagen. Imidlertid erfarte sykepleierne at PLO-meldingene ikke understøttet alle aspekter ved deres kommunikasjonsbehov. De brukte derfor supplerende kommunikasjonskanaler for å sikre informasjonskontinuitet. Dermed unngikk de uheldige konsekvenser for pasienten. Dette utfordrer samhandlingsformens målsetting om at elektronisk kommunikasjon skal være den foretrukne måten å kommunisere på mellom helsepersonell (1).

Elektronisk meldingsutveksling måtte suppleres med muntlig tale og møter for å avklare og utdype tvetydigheter, og/ eller innhente tilleggsinformasjon. Årsaken til dette omfattet uforutsigbarhet knyttet til pasientens utreisedato, inkonsistens mellom pasientens legemiddelliste i kommunen og $\mathrm{i}$ sykehus, manglende informasjon i meldinger og forskjeller i faglig tilnærming mellom nivåene. På denne måten nyanserer studiens funn bildet av tidligere rapporterte gevinster med elektronisk meldingsutveksling. Disse forteller om økt tilgjengelighet til nødvendig helseinformasjon og bedre kvalitet på innholdet $\mathrm{i}$ informasjonen som overføres (26). Funnene er likevel i tråd med annen forskning som konstaterer at elektroniske kommunikasjonsløsninger i helsetjenesten ofte må suppleres med andre kommunikasjonskanaler (31-34).

Behovet for å supplere med andre kommunikasjonskanaler (telefon og vurderingsbesøk) for å innhente tilstrekkelig og relevant informasjon om pasienten var spesielt uttalt blant sykepleierne i kommunen. De måtte ofte gå utenom meldingssystemet for å sikre pasientbehandlingen. Dette skyldtes inkonsistens mellom pasientens medbrakte legemiddelliste (i papirformat) fra sykehuset og den legemiddellista pasienten stod på før innleggelse. I samsvar med eksempler fra litteraturen viser denne studien at manuell informasjonsutveksling om legemidler kunne representere en trussel for pasientsikkerheten $(35,36)$. Dette gjenspeilte seg ikke der elektronisk legemiddelliste var tatt i bruk $(25,37)$.

Behovet for bruk av supplerende kommunikasjonskanaler var også knyttet til informasjonsinnholdet i oversendte meldinger fra sykehus til kommune, for eksempel «Tidligmeldingen» som initierte utskrivningsforløpet. I samsvar med funn fra ling. Kommunens sykepleiere hadde på sin side behov for å motta informasjon om pasientens helhetlige funksjonsnivå, hjelpebehov og preferanser. Slik informasjon var nødvendig for å kunne prioritere de sykeste for videre helsehjelp ved et sykehjem. Dette var også nødvendig for å tilrettelegge for helsehjelp og hjelpemidler før pasientens hjemkomst, og dermed unngå utsettelse av pasientbehandling og oppfølging (18). Behovet for muntlige avklaringer og tilleggsinformasjon var ekstra tydelig for pasienter som ikke tidligere hadde vært brukere av kommunale tjenester, den såkalte "0-brukeren».

Standardiserte PLO-meldinger er basert på standard innholdselementer med muligheter for å skrive fritekst. Våre funn viser at sykepleierne opplevde bruken av fritekst i PLOmeldingene som utfordrende. Selv om sykehusets sykepleiere kunne høste tekstinnhold fra elektronisk pasientjournal, så rapporterte de om individuelle forskjeller i hvordan de fylte ut meldingene. Dette gjaldt for eksempel hvor rik tekstbeskrivelsen var og hvilke felter de benyttet. Samtidig viser resul-

\section{Våre funn viser at sykepleierne opplevde bruken av fritekst i PLO-meldingene som utfordrende.}

studier fra før meldingssystemet ble innført $(12,13)$ hadde sykepleierne i sykehus og kommune fortsatt ulik faglig tilnærming til pasientens helsetilstand. Sykehusets sykepleiere knyttet meldingsinformasjonen til diagnose og behandling, for eksempel at pasienten var innlagt med lungebetennelse og skulle ha intravenøs antibiotikabehand- tatene fra en nylig publisert artikkel at det å skrive meldinger som blir lagret i journalsystemet, gjør at sykepleierne blir mer bevisste på hvordan de uttrykker seg skriftlig (38).

Bruk av fritekst med individuelle ordvalg og formuleringer gjorde at sykehusets dokumentasjon av helsehjelp og pasientens funksjonsnivå kunne fremstå 
som noe ufullstendig for mottakeren, kommunen. En mulig forklaring var at journalen gir rom for ustrukturert dokumentasjon og at det var overlappende arbeid på grunn av likheten mellom «Helseopplysningsskjemaet» og «Utskrivningsrapporten». Men nyere litteratur peker også på forklaringsfaktorer som at det er ulike journalsystemer ved sykehus og kommune, og at profesjonen mangler en standardisert nasjonal modell for sykepleiernes journalføring (22). Det at helse-

mottatt melding, eventuelt hvor kjent denne er innenfor en organisasjon (25). For sykepleierne ved begge nivåer var det viktig å få beskjed om at meldingene var mottatt og lest.

\section{Studiens begrensninger}

Utvalget av ett sykehus og tre kommuner er for lite til at vi kan trekke generelle konklusjoner om sykepleiernes erfaringer med bruk av PLO-meldinger ved utskrivning av pasienter fra sykehus til hjemmetjeneste.

\section{Sykepleiere i både sykehus og kommune hadde behov for å vite at meldinger var mottatt av samhandlende helsepersonell.}

personell kommuniserer på et omforent fagspråk, semantisk interoperabilitet (22), er en viktig forutsetning for utveksling og deling av informasjon på tvers av nivåer.

Teknologien kan åpne opp for nye måter å jobbe på (39). Et noe overraskende funn i denne studien var at sykepleiere ved både sykehus og kommune benyttet PLO-meldingene til å holde oversikt over pasientstrømmer. Dette gjorde de selv om praksis varierte innad og mellom nivåer. En mulig forklaring kan tilskrives uforutsigbarheten rundt pasientens forventede utreisedato fra sykehuset. Kommunene erfarte for eksempel å få mange endringsmeldinger rundt pasienters utreisedato. Dette kompliserte deres oversikt over egne brukere. De måtte passe på at pasientene ikke ramlet ut av systemet så vel som å tilpasse planlegging av tjenestetilbud og ressurser. En annen forklaring kan knyttes til hvorvidt PLOmeldingssystemet har en funksjon for tilbakemeldinger på
Vi har heller ikke tatt hensyn til organisatoriske faktorer eller hvor lenge PLO-meldingene har vært i bruk ved de ulike enheter. Studiens gyldighet støttes imidlertid ved at funnene drøftes opp mot tidligere forskning.

\section{KONKLUSJON}

PLO-meldinger er et nyttig kommunikasjonsverktøy i utskrivningsprosessen. Men det må kompletteres med muntlig kommunikasjon og møter for å ivareta informasjonskontinuitet ved utskrivningsplanlegging og utskrivning av pasienter fra sykehus til hjemmetjeneste. For å styrke meldingsutvekslingssystemets rolle som kommunikasjonsredskap, er det nødvendig å arbeide videre med innholdet i meldingenes fritekstfelter. Det er også en forutsetning å få til en felles forståelse for informasjonsbehovet på tvers av helsetjenestenivåer.

Studien er støttet av Norges Forsk-ningsråd, NFR prosjekt nr. 229623-SIKT (EVASAMprogrammet).

\section{REFERANSER}

1. St.meld. nr. 47 (2008-2009). Samhandlingsreformen: Rett behandling på rett sted - til rett tid. Oslo: Helse-og Omsorgsdepartementet (HOD); 2012.

2. Norskhelsenett årsrapport 2013. Norsk Helsenett; Tilgjengelig fra: https://www.nhn.no/om-oss/Documents/arsrapport-NHN-2013.pdf. Nedlastet 21-10-2015.

3. Bauer M, Fitzgerald L, Haesler E, Manfrin M. Hospital discharge planning for frail older people and their family. Are we delivering best practice? A review of the evidence. Journal of Clinical Nursing. 2009;18(18):2539-46.

4. KS FOU-prosjekt nr. 124005. Utskrivningsklare pasienter endrer praksis seg. Oslo: Rambøll Mangement Consulting, 2012. Tilgjengelig fra: http://www.ks.no/ contentassets/dffac $809 f 5934 \mathrm{f4bbf-}$ 69 c8348c5c47ec/124005_rapport- utskrivningsklare-pasienter.pdf. Nedlastet 21-10-2015.

5. Olsen RM, Hellzén 0, Enmarker I. Nurses' information exchange during older patient transfer: prevalence and associations with patient and transfer characteristics. International Journal of Integrated Care, mars 2013. ISSN 1568-4156. Tilgjengelig fra: http://www. ijic.org/index.php/ijic/article/view/879. Nedlastet 21-10-2015.

6. Olsen RM, Hellzén O, Skotnes LH, Enmarker I. Breakdown in informational continuity of care during hospitalization of older home-living patients: a case study. International Journal of Integrated Care, mai 2014. ISSN 1568 4156. Tilgjengelig fra: http://www.ijic. org/index.php/ijic/article/view/1525. Nedlastet 21-10-2015.

7. Storm M, Siemsen IMD, Laugaland KA, Dyrstad DN, Aase K. Quality in transitional care of the elderly: Key challenges and relevant improvement measures. International Journal of Integrated Care. Mai 2014. ISSN 1568 4156. Tilgjengelig fra: http://www.ijic. org/index.php/ijic/article/view/URN\% 3ANBN\%3ANL\%3AUI\%3A10-1-114780. Nedlastet 21-10-2015.

8. Danielsen B, Fjær S. Erfaringer med å overføre syke eldre pasienter fra sykehus til kommune. Sykepleien Forskning. 2010;5(1):28-34

9. Hellesø R, Lorensen M, Sorensen L. Challenging the information gap the patients transfer from hospital to home health care. International Journal of Medical Informatics. 2004;73178):569-80.

10. Innspill til Helse- og omsorgsministerens arbeid med samhandlingsreformen. Statens helsetilsyn, 2008. Tilgjengelig fra: https://helsetilsynet.no/no/Publikasjoner/ 
Brev-hoeringsuttalelser/Utvalgtebrev-og-horingsuttalelser-tidligerear/Innspill-samhandlingsreformen/. Nedlasted: 21-10-2015.

11. Shah F, Burack O, Boockvar KS. Perceived Barriers to Communication Between Hospital and Nursing Home at Time of Patient Transfer. Journal of the American Medical Directors Association. 2010;11(4):239-45.

12. Hellesø R, Fagermoen MS. Cultural diversity between hospital and community nurses: implications for continuity of care. International Journal of Integrated Care. Feb 2010. ISSN 1568-4156. Tilgjengelig fra: http://www. ijic.org/index.php/ijic/article/view/508. Nedlasted: 21-10-2015.

13. Valaker I. Et helhetlig behandlingsforløp -om samhandling rundt pasienter. I: Bukve O, Kvåle G (red). Samhandling og kvalitet i helseorganisasjoner. Oslo: Universitetsforlaget AS; 2014.

14. Naustdal A-G, Netteland G. Sjukepleiedokumentasjon i eit elektronisk samhandlingsperspektiv. Sykepleien Forskning. 2012;7(3): 270-7.

15. Heimly V, Hygen J. The Norwegian Coordination Reform and the Role of Electronic Collaboration. Electronic Journals of Health Informatics. 2011;6(4). Tilgjengelig fra: http://www. ejhi.net/ojs/index.php/ejhi/article/ view/176. Nedlastet:21-10-2015.

16. Marcotte L, Kirtane J, Lynn J, McKethan A. Integrating Health Information Technology to Achieve Seamless Care Transitions. Journal of Patient Safety. 2015. Tilgjengelig fra: http://journals.lww.com/journalpatientsafety/Fulltext/publishahead/ Integrating_Health_Information_Technology_to.99789.aspx. Nedlastet: 21-102015 .

17. Hewner S, Seo JY. Informatics' Role in Integrating Population and Patientcentered Knowledge to improve Care Transitions in Complex Chronic Disease. Online Journal of Nursing Informatics. 2014;18(2). Tilgjengelig fra: http://www.himss.org/resourcelibrary/ TopicList.aspx? MetaDatalD=3055. Nedlastet: 21-10-2015.

18. Netteland G, Naustdal A-G. Risikofaktorer ved overganger. I: Bukve 0 , Kvåle G(red). Samhandling og kvalitet $i$ helseorganisasjoner. Oslo: Universitetsforlaget AS; 2014.

19. Dunnion ME, Kelly B. All referrals completed? The issues of liaison and documentation when discharging older people from an emergency department to home. Journal of Clinical Nursing. 2008;17(18):2471-9.

20. Berntsen G, Høyem A, Gammon D. Helsetjenesten sett fra pasientens ståsted. Troms $\varnothing$ : Nasjonalt senter for samhandling og telemedisin, Universi- tetssykehuset Nord-Norge; 2014. NSTrapport 07-2014.

21. Helsedirektoratet. Veiviser - Hvordan komme i gang med elektronisk meldingsutveksling i kommunen. IS-1920. Oslo 2011. Tilgjengelig fra: https:// helsedirektoratet.no/retningslinjer/ veiviser-hvordan-komme-i-gangmed-elektronisk-meldingsutvekslingi-kommunen. (Nedlastet:21-10-2015).

22. Svanes M, Nyhus VÅ, Hagen 0 , Bømark SR, Vabo G, Holen-Rabbersvik E. Veileder for klinisk dokumentasjon av sykepleie i EPJ (v. 5.0). Norsk Sykepleierforbunds Faggruppe for e-helse. 2015. Tilgjengelig fra: https://www.nsf. no/vis-artikkel/2481424/10503/Nyveileder-for-klinisk-dokumentasjonsykepleie. Nedlastet: 08-10-2015.

23. Slagsvold $\mathrm{H}$. Meldingsutbredelse kommunehelsetjenesten. Norsk Helsenett SF, 2015. tilgjengelig fra: https:// nhn.no/aktuelt/Documents/vedlegg/ KomUT-sluttrapport.pdf. (Nedlastet: 21-10-2015).

24. Holte H, Lidal I, Gundersen M. Utskrivning av pasienter med kronisk sykdom: effekt av ulike former for samhandling mellom sykehus og kommunehelsetjeneste. Rapport fra Kunnskapssenteret - Systematisk oversikt. 2013. Tilgjengelig fra: http://www.kunnskapssenteret.no/ publikasjoner/utskrivning-av-pasienter-med-kronisk-sykdom-effekt-av-ulike-former-for-samhandling-mellomsykehus-og-kommunehelsetjeneste. (Nedlastet:25-05-2015).

25. Borgen K, Melby L, Hellesø R, Steinsbekk A. Elektronisk meldingsutveksling mellom hjemmetjenestene og fastleger. Sykepleien Forskning. 2015;10(1):42-8

26. PricewaterhouseCoopers. Gode modeller for elektronisk meldingsutveksling $\mathrm{i}$ helsesektoren. Kostnader og gevinster for små kommuner. På oppdrag fra KS og Norsk Helsenett. 2014. Tilgjengelig fra: http://www. ks.no/fagomrader/utvikling/fou/fourapporter/fou-elektroniske-meldingergir-gevinster-for-sma-kommuner/. (Nedlasted:21-10-2015).

27. Haggerty JL, Reid RJ, Freeman GK, Starfield BH, Adair CE, McKendry R. Continuity of care: a multidisciplinary review. BMJ 2003:327:1219.

28. Reid RJ, Haggerty JL, McKendry R. Defusing the confusion: Concepts and Measures of Continuity of Healthcare: Canadian health Services Research Foundation; 2002. Tilgjengelig fra: http://www.cfhi-fcass. ca/SearchResults News/02-03. 01/58a53ce8-39f2-466a-8e98-8ffc36cf456c.aspx.nedlastet:15-10-2015. 29. Tjora AH. Kvalitative forskningsmetoder i praksis. Oslo: Gyldendal akademisk; 2012.
30. Malterud K. Kvalitative metoder i medisinsk forskning: en innføring. Oslo: Universitetsforlaget; 2011.

31. Paulsen B, Romøren TI, Grimsmo A. A collaborative chain out of phase. International Journal of Integrated Care. Mars 2013. ISSN 1568-4156. Tilgjengelig fra: http://www.ijic.org/index. php/ijic/article/view/URN\%3ANBN\%3 ANL\%3AUI\%3A10-1-114285. Nedlastet:11-05-2015

32. Brattheim BJ, Toussaint PJ, Faxvaag $A$. When Information Sharing is not Enough. Stud Health Technol Inform. 2011;169:359-63

33. Mäenpää T, Suominen T, Asikainen P, Maass M, Rostila I. The outcomes of regional healthcare information systems in health care: A review of the research literature. International Journal of Medical Informatics. 2009:78(11):757-71.

34. Nordberg M. Elektronisk sykepleierapport utfordrer sykepleiekontinuiteten. Sykepleien Fag. 2015(02):50-3. 35. Frydenberg K, Brekke M. Poor communication on patients medication across health care levels leads to potentially harmful medication errors. Scandinavian Journal of Primary Health Care. 2012;30(4):234-40.

36. Kohn LT, Corrigan J, Donaldson MS. To err is human: building a safer health system. Washington, D.C.: National Academy Press; 2000.

37. Lyngstad M, Melby L, Grimsmo A, Hellesø R. Toward Increased Patient Safety? Electronic Communication of Medication Information Between Nurses in Home Health Care and General Practitioners. Home Health Care Management \& Practice. 2013; 25(5): 203-211.

38. Melby L, Brattheim BJ, Hellesø R. Patients in transition - improving hospital - home care collaboration through electronic messaging: providers' perspectives. Journal of Clinical Nursing. 2015 Sep 15. doi: 10.1111/jocn.12991. [Epub ahead of print].

39. Vimarlund V, Olve $\mathrm{N}-\mathrm{g}$, Scandurra I, Koch S. Organizational effects of information and communication technology (ICT) in elderly homecare: a case study. Health Informatics Journal. 2008;14(3):195-210.

40. Vestlandsheftet. Veileder for utbredelse av elektroniske meldinger mellom kommune, fastlege og helseforetak på Vestlandet. Tilgjengelig fra: https://www.bergen.kommune. no/bk/multimedia/archive/00152/ Veilederen_p__bokm__152543a.pdf. Nedlastet: $21-10-2015$.

Les kommentaren på side 34 》 